\title{
The Impact of the Prehistoric Polynesians on the Hawaiian Ecosystem ${ }^{1}$
}

\author{
PATRICK V. KIRCH ${ }^{2}$
}

\begin{abstract}
Evidence obtained from archaeological and ancillary studies of paleoenvironment suggests that the prehistoric Polynesians had a far greater impact on the Hawaiian ecosystem than has heretofore been realized. Such impact began with the introduction, by Polynesians, of exotic plants and animals. The cumulative effects of forest clearance and habitat modification through the use of fire led to major changes in lowland ecology. Among the consequences of this transformation of the Hawaiian landscape were the extinction of endemic species, alteration of vegetation communities, and erosion.
\end{abstract}

THE EXTANT BIOTA of the Hawaiian Islands represents a sadly depauperate reflection of the archipelago's flora and fauna prior to the advent of humans. This observation is not likely to startle most naturalists familiar with Hawaiian natural history. However, the consensus has long been that by far the greatest human impact on the Hawaiian ecosystem occurred in the two centuries since initial European contact. Carlquist, for instance, attributes the removal of large tracts of native dry forest to the actions of "peoples other than the Polynesians" (1970:275). Indeed, it has been commonly assumed that the impact of the indigenous Polynesian inhabitants of Hawaii was minimal. The anthropologist Kelly maintained that "works of Hawaiians, both on land and in the sea, were so carefully planned, engineered and executed that they enhanced productivity without massive environmental degradation" (1975:iii, emphasis added).

Sufficient evidence is now available (accumulated largely over the past decade by archaeologists with interdisciplinary support from a range of natural sciences) to question seriously the orthodox view regarding minimal prehistoric Polynesian impact on the Hawaiian environment. In fairness, I must note that some naturalists have realized the

\footnotetext{
${ }^{1}$ Manuscript accepted 30 October 1981.

${ }^{2}$ Bernice P. Bishop Museum, Department of Anthropology, P.O. Box 19000-A, Honolulu, Hawaii 96819.
}

potential of prehistoric Polynesians to disrupt their island environments. Zimmerman, for example, opined that prior to the Polynesian colonization of Hawaii, the land was "densely forested down to the seashore," and that "the fires of even the early Polynesians swept away vast tracts of woodland" (1963:57-8). Similar views have been expresed by Atkinson (1977), Degener and Degener (1974), Egler (1942), Fosberg (1972), and Newman (n.d.). Nevertheless, until quite recently there has been a dearth of direct, paleoenvironmental data bearing on the question of pre-European human impact on the Hawaiian ecosystem.

This paper provides a synopsis of such evidence from the viewpoint of an archaeologist who has been actively engaged in research on the question of human-environment interaction in Polynesia. I believe such a synopsis to be timely for at least two reasons: First, the popular orthodoxy of indigenous peoples in symbiotic "harmony" with nature should not go unquestioned. Second, by presenting the evidence thus far accumulated, other natural scientists may be inspired to contribute their analytical efforts, and the archaeological study of human-environment relations requires interdisciplinary cooperation. I hasten to add that over the course of the past decade of investigations, far more questions than answers have emerged. Some of the most startling evidence regarding, for example, avifaunal extinctions and shoreline changes has been obtained only within the past year or 
two. Clearly, the synopsis given here is of a rapidly changing area of research.

\section{ARCHAEOLOGY AND PALEOECOLOGY IN HAWAII}

Scientific archaeology utilizing the methods of stratigraphic excavation accompanied by precise chronological control is barely three decades old in Hawaii. With the discovery by Emory (in 1950) that the Hawaiian occupation of the archipelago was of considerably longer duration than originally supposed, a program of excavation was initiated, aimed at establishing a culture-historical sequence. This initial phase of investigations was strongly cultural in orientation, with emphasis placed upon delineation of artifact types and sequences. Although some attention was focused on the faunal and botanical evidence for prehistoric Hawaiian environmental exploitation and subsistence (Bonk 1954), there was little overt concern with defining the nature of humanenvironment interaction. The impact of humans on the Hawaiian environment was a nonexistent question.

Research orientations in Hawaiian archaeology underwent a substantial transition in the late 1960 s and early 1970 s, largely through the application of the "settlement pattern" approach. Investigators began to consider how microenvironmental variation influenced the varieties of ecological adaptations witnessed in the Hawaiian archaeological record. Out of these initial settlement pattern studies, especially those focusing upon Makaha, Halawa, and Lapakahi (Green 1969, 1970, Kirch and Kelly 1975, Ladd and Yen 1972, Rosendahl 1972a, Tuggle and Griffin 1973), came the first detailed evidence that the Hawaiian environment had not been a stable, changeless monolith during the course of prehistoric human tenure. Evidence of local but massive slope erosion in Makaha and Halawa, and of deforestation at Lapakahi were among the signs that human activities had wrought substantial environmental change.

Most Hawaiian archaeologists have now come to the realization that neither the contact period Hawaiian culture nor its environ- ment can be adequately comprehended except as the product of some 1400 years of dynamic interaction. Variability and constraint inherent in the Hawaiian environment have been powerful forces in molding the particular form of Hawaiian culture from a colonizing archaic Polynesian ancestor. At the same time, Hawaiian adaptation to environment was anything but passive, for, like all human populations, the prehistoric Polynesian inhabitants of Hawaii actively manipulated and modified their habitat. This kind of interaction is reciprocal, because culture "transforms its landscape and so must respond anew to changes that it had set in motion" (Sahlins 1964:133). Just as the evolutionary development of a "natural" ecosystem must be regarded as the coevolution of its constituent species, so the prehistory of humans in the Hawaiian archipelago must be understood in coevolutionary terms.

\section{TRANSPORTED LANDSCAPES}

Edgar Anderson set out the bold concept of "transported landscapes" based upon his research with the adventive, ruderal floras of North America. He wrote: "unconsciously as well as deliberately man carries whole floras about the globe with him, ... he now lives surrounded by transported landscapes, [and] ... our commonest everyday plants have been transformed by their long associations with us so that many roadside and dooryard plants are artifacts" (1952:9). Although Anderson was concerned primarily with weeds and cultigens, his concept of transported landscapes epitomizes the effects of human colonization of a natural ecosystem. By means of both purposeful and accidental transport of adventive plants and animals, humans alter the biota of any new habitat. In oceanic islands, the introduction of highly competitive weeds and predators had drastic effects on the vulnerable endemic biota (cf. Fosberg 1963:5). In the colonization of new lands, however, humans do more than act as the means of transport for a group of adventives. They carry with them a cultural concept of landscape, which causes them to actively shape a 
new environment in that mold. For Polynesians, this cultural concept of landscape, transferred from previously settled archipelagoes in the south and southwest Pacific, included such notions as the suitability of valley bottoms for irrigated terracing and the efficacy of fire in converting forest into shifting cultivations. At the time of initial settlement by humans, the Hawaiian archipelago could be likened to a canvas upon which a cultural landscape was gradually to replace a scene of great natural diversity.

Natural scientists have long been seduced by the endemic biota of Hawaii, yet, as Bates argued, "the adventive fauna [and flora] comprises, really, a sort of gigantic, unplanned ecological experiment that might also yield information of great biological interest" (1956:796). It is clear that the history of these adventives and of purposefully introduced biota began with the first Polynesian colonization. Direct archaeological evidence for the introduction of several species has come from the earliest known habitation sites at Bellows, Oahu (Pearson, Kirch, and Pietrusewsky 1971), and at Halawa, Molokai (Kirch and Kelly 1975). Skeletal remains of domestic pig and dog (Sus scrofa, Canis familiaris) were recovered at both sites, while those of the fowl (Gallus gallus) are known from other early sites on Hawaii Island. The Polynesian rat (Rattus exulans) was also carried on the initial settlement voyages, probably as an inadvertent stowaway (Tate 1951). Geckos and skinks (Gekkonidae, Scincidae; Stejneger 1899) were also stowaways on Polynesian voyaging canoes; their minute skeletal remains have not been reported from the early settlement sites, but gecko and skink mandibles have been found in prehistoric avifaunal deposits at Barbers Point, Oahu, in association with introduced land snails (Kirch and Christensen 1980; see below). Even though direct botanical evidence is lacking, there is no doubt that the Polynesian colonizers were agriculturalists who brought with them a full complement of oceanic crop plants. The Bellows and Halawa sites were permanent settlements, with considerable indirect evidence of an agricultural subsistence base. Furthermore, excavations at Hanalei
Valley on Kauai Island have revealed typical pondfield soil horizons, indicative of taro irrigation, with an associated carbon-14 age determination of A.D. $610 \pm 95$ (Schilt 1980).

In addition to the introduced vertebrates and cultigens, there is evidence that a host of invertebrates and weeds accompanied the colonizing Polynesians. Anderson (1952:15) maintained that "the history of weeds is the history of man," a history that for the Pacific islands remains largely unknown. St. John (1978) has shown that on the basis of the collections and observations of David Nelson (botanist on Cook's third expedition in 1779), several weeds were established in Hawaii prior to European contact as the result of accidental dispersal by Polynesians. These weeds include Ludwigia octivalvis, Oxalis corniculata, Urena lobata, Thelypteris interrupta, Digitaria setigera, Waltheria indica, and Merremia aegyptia (St. John 1978:316). As St. John notes, Thelypteris and Ludwigia frequent wet habitats, particularly irrigated taro pondfields. (In 1974, I observed Ludwigia to be one of the dominant and persistent weeds in the native taro fields of Futuna Island.) "The spores or seeds of both plants could have been close to growing taro in Tahiti [or the Marquesas], and could have been in the mud packed around the taro corms in transit to Hawaii" (St. John 1978:316). Similarly, "Digitaria abounds about pig pens" (1978:317) and may have accompanied the first swine to Hawaii; its native name, kukaepua'a, "pig feces," underscores this relationship with swine.

Allen (1981) has reported on preserved seeds of four weedy species from prehistoric contexts in a rock shelter site at the Mauna Kea Adz Quarry on Hawaii Island: Oxalis corniculata, Daucus sp., Solanum nigrum, and Adenostemma lavenia. The future application of paleoethnobotanical analyses can be expected to provide additional information on the introduction of cultigens and weeds to Hawaii.

Malacologists have long regarded several widespread Pacific snails as having been dispersed by the prehistoric oceanic peoples (Cooke 1926, Cooke and Kondo 1960, Pilsbry 1916-1918, Solem 1959). At least three species appear to have reached Hawaii prior 
to European contact: Lamellaxis gracilis, Lamellidea oblonga, and Gastrocopta pediculus. The first of these, Lamellaxis gracilis, is common in several early oceanic archaeological sites (Christensen and Kirch 1981) and occurs in Hawaii in the Barbers Point paleontological sites in association with extinct avifauna (see below).

It would be surprising if arthropods were not also transported by the Polynesians. Unfortunately, there are no early entomological collections to indicate which of the adventive insects may have been present prior to European contact. However, it does appear that ectoparasites (such as Laelaps hawaiiensis) accompanied the Polynesian rats; the same species of ectoparasite has been reported from rats in both Hawaii and the Marquesas (Ewing 1924, Ferris 1932).

In short, the process of conversion of a natural ecosystem into an actively manipulated cultural landscape began with the colonization of Hawaii by Polynesians ca. A.D. 400. The purposeful introduction of domestic animals and crop plants, and the inadvertent dispersal of rats, geckos, skinks, snails, arthropods, and weeds marked the beginning of a gradual transformation of the loweraltitude Hawaiian biota. To understand this transformation and its full impact upon the Hawaiian environment we need to consider the sequence of human population growth and agricultural development over the 14 centuries from initial colonization to European contact.

\section{POPULATION, AGRICULTURE, AND ENVIRONMENT}

Schmitt (1971) conservatively estimated that the indigenous Polynesian population of Hawaii numbered no less than 200,000 persons at the time of initial European contact. Given that the habitable portion of the principal islands (i.e., those areas excluding steep cliffs and land over $880 \mathrm{~m}$ elevation) equals about $9000 \mathrm{~km}^{2}$, this population had an average density on the order of 22 persons/ $\mathrm{km}^{2}$, although densities obviously varied from area to area and were considerably higher in the fertile valleys (e.g., $250 / \mathrm{km}^{2}$ in Halawa Valley, Molokai) and in other agriculturally productive regions. This large population developed over the centuries through internal growth (and not from largescale immigration), from a relatively small founding propagule-perhaps less than 100 persons.

Several studies have relied on archaeological data to produce models of prehistoric Hawaiian demographic change (Cordy 1978, Hommon 1976, Kirch 1980) based on the reasonable assumption that the number of permanent habitation sites at any given time is allometrically related to the size of the population inhabiting them (cf. Ammerman, Cavalli-Sforza, and Wagener 1976). Figure 1 is a histogram of a sample of 170 dated habitation sites (primarily from Hawaii Island, with 47 sites from Oahu, Molokai, and Maui), showing the number of occupied sites per 100year interval. Given the assumed relationship between habitation sites and population, the shape of this site-population histogram should reflect the shape of the actual population growth curve from the time of initial colonization to European contact. Two features of this curve deserve special attention: (1) In overall shape, the curve is sigmoid, with initial exponential growth (intrinsic rate, $r$, about 0.008 ), followed by a slowing of the growth rate, with a peak $(r=0)$ reached about A.D. 1650. (2) There appears to have been a significant decrease in population from A.D. 1650 to the time of initial European contact ( $r$ about -0.03). Hommon (1980) has analyzed a series of 655 dated sites from the island of Kaho'olawe, which show a parallel population growth curve, with a peak ca. A.D. 1500-1550, and subsequent decline.

These paleodemographic data are replete with implications for the dynamic relationship between the prehistoric Hawaiian population and its insular environment. The evidence that population growth had reached a peak, and was even on the decline, prior to European contact strongly suggests that the capacity of the indigenous technological productive system to support increased population had reached its limits. The data also pose a further question: Was the late prehistoric demographic decrease a response, in 


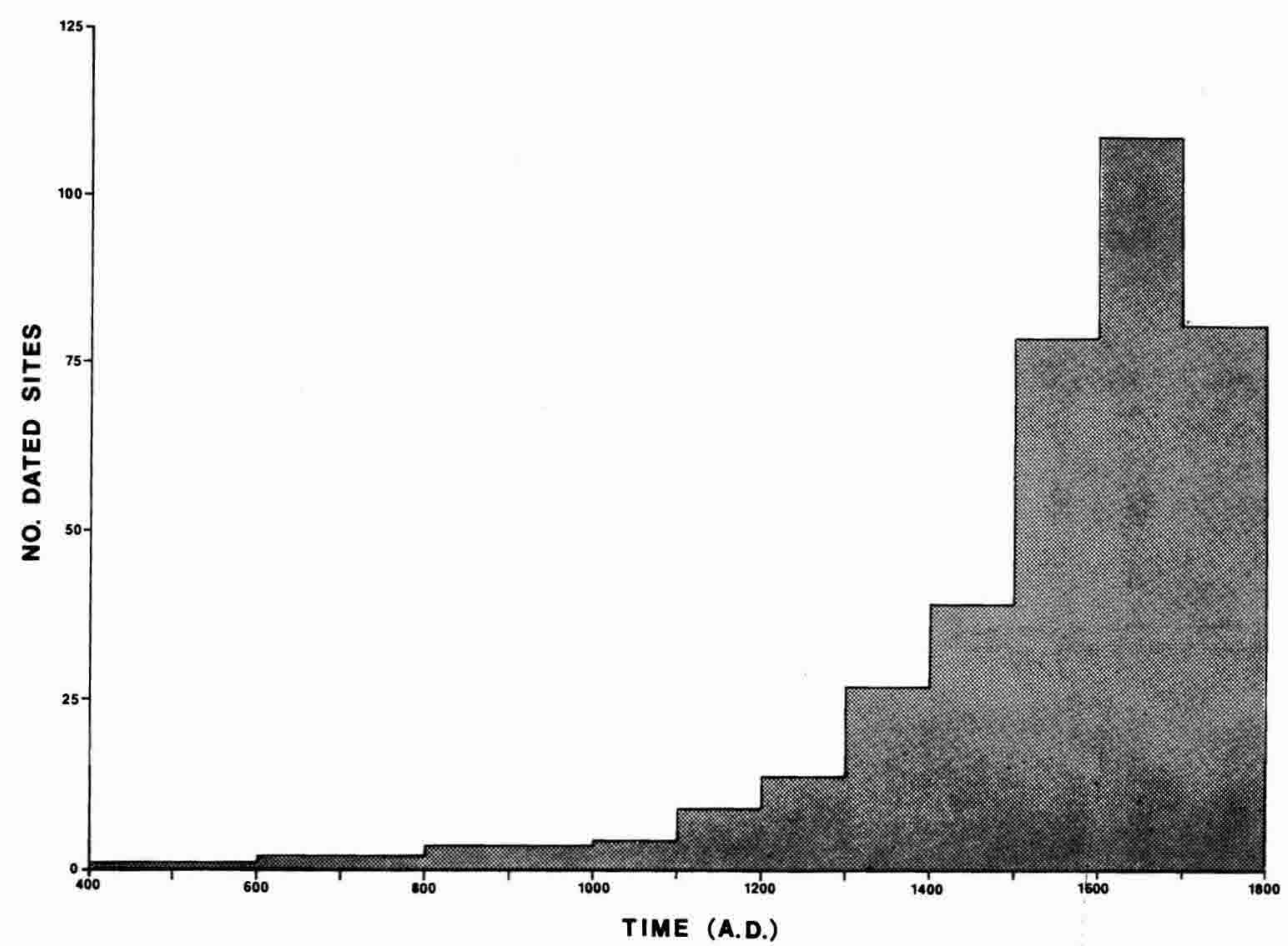

FIGURE 1. Histogram of dated prehistoric habitation sites from the islands of Hawaii, Maui, Molokai, and Oahu.

part at least, to deterioration of the environment and consequent reduction in carrying capacity? Archaeological investigation of prehistoric Hawaiian agricultural systems conducted over the past decade provide partial answers to these fundamental questions.

In the most general terms, oceanic agricultural systems can be categorized into two basic types: (1) water-control systems, which create artificial hydrologic-edaphic media suitable for the intensive cultivation of taro (Colocasia esculenta); and (2) extensive systems of shifting cultivation ("slash-andburn") utilizing fire as the primary means of vegetation clearance, and involving a range of crop plants, including yams (Dioscorea spp.), aroids (Colocasia and Alocasia), and bananas (Musa hybrids) (Barrau 1965, Yen 1973). Both kinds of systems were part of the cultural concept of landscape transported by the earliest Polynesian colonizers of Hawaii. Over the ensuing one and a half millennia these systems were adapted, expanded, and intensified until they had come to dominate the lowland landscape of the archipelago. There is scarsely an area in the lowlands (if it receives greater than $500 \mathrm{~mm}$ rainfall and is not steep cliff) that upon archaeological reconnaissance does not yield evidence of indigenous Polynesian agricultural use.

I have already noted the recently obtained carbon-14 date from Hanalei Valley, Kauai Island, indicative of pondfield irrigation by ca. A.D. 600 . Excavations in Halawa, Molokai, and Makaha, Oahu (Kirch and Kelly 1975, Yen et al. 1972), demonstrated the conversion of inland alluvial flats and terraces to pondfield irrigation ca. A.D. 1200-1400, the period of rapid population increase according to the paleodemographic reconstructions. By the advent of Europeans, virtually all valley bottoms with permanent stream flow had been transformed into reticulate irrigation networks (Earle 1978, Handy and Handy 1972, Kirch 1977). This technological transformation of the environment obviously created substantial areas of ponded, marshy habitat. Olson and James (in press) have suggested 
that this new, man-made aquatic habitat provided an opportunity for ducks (Anas platyrhynchos), gallinules (Gallinula chloropus sandvicensis), and coots (Fulica americana alai) to establish permanent colonies in the archipelago. "The extensive Polynesian cultivation of taro in flooded pondfields would have provided much more suitable habitat for the duck and the gallinule than ever existed previously" (Olson and James, in press). The absence of these species from the abundant Pleistocene avifaunal deposits may be taken as tentative evidence that they did not become established (or at least abundant) until humans created the appropriate habitats.

The expansion of shifting cultivation out of the ecologically favorable valleys to the more arid leeward areas resulted in even greater impacts upon the Hawaiian ecosystem. The adaptability of the sweet potato (Yen 1974) aided immeasurably in the extension of this type of indigenous cultivation to the more arid portions of the islands. Archaeological studies on the western side of Hawaii Island have produced an outline of the temporal and spatial axes of agricultural development (Kirch 1981b, Newman n.d., Rosendahl 1972a, Soehren and Newman 1968). Several large field systems began to be developed about A.D. 1300 in North Kohala, Kona, and Waimea. As population increased to A.D. 1650, these systems underwent both expansion (to the limits of suitable soil and rainfall conditions) and intensification (in cropping interval, labor input, construction of permanent field borders, and animal husbandry). Clearly, the development of these systems was accompanied by the simultaneous removal of vast tracts of native xerophytic and mesophytic plant communities with the aid of fire. From all three field systems we now have stratigraphic evidence of "burn layers," with associated deposits of endemic land snails, indicative of former park land or dry forest conditions (Christensen in Kirch and Clause 1981, Rosendahl 1972a). Analyses (in process) of pollen, opal phytoliths, and charcoal from agricultural and preagricultural soil horizons at Lalamilo and Pua'a, Kona, may aid in reconstructing more precisely the

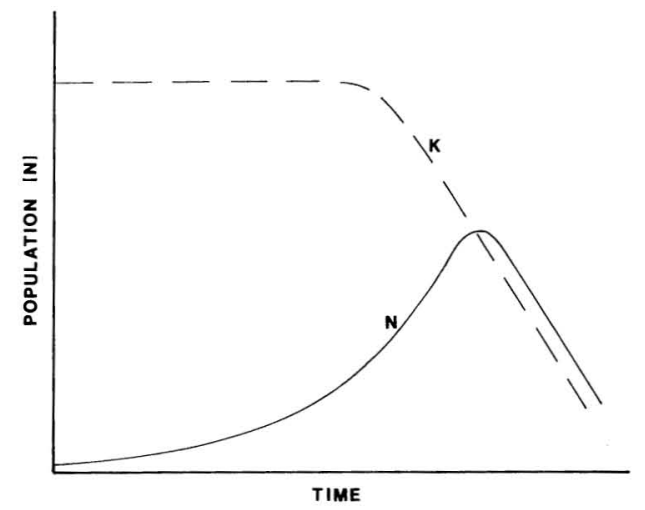

FIGURE 2. Hypothetical relationship between human population growth $(\mathrm{N})$ and carrying capacity $(\mathrm{K})$ in prehistoric Hawaii. Environmental degradation may have led to a lowering of carrying capacity, which in turn affected the size of the human population.

nature of the leeward vegetation prior to the great agricultural expansion that occurred between A.D. 1300 and 1700 .

As a result of population increase and concomitant agricultural development, the greater part of the lowland landscape of the archipelago had been converted to a thoroughly artificial ecosystem prior to European advent. Only the higher forested regions (generally above $760 \mathrm{~m}$ ) and alpine zones were left relatively undisturbed, although even these were subjected to less severe forms of exploitation (for stone, wild birds, wood, and other forest products). A fundamental question-which we are as yet unable to answer definitively - is whether this ecological transformation of nature into culture had a reciprocal, feedback effect on the human population by reducing the size of the population that could be supported, given the technological repertoire of Polynesian agriculturalists. The data obtained to date suggest that at least some aspects of this transformation should be regarded as true environmental degradation. The strongest evidence for a reduction in carrying capacity, though indirect, is the decline and reduction in population growth itself. Figure 2 is a diagrammatic representation of what the relationship between population $(\mathrm{N})$ and carrying capacity $(\mathrm{K})$ may have been over the course of the pre- 
historic human tenure of the islands. For the present, this diagram must be regarded as representing no more than an hypothesis, but unquestionably one of the utmost significance to anthropologists and naturalists alike.

\section{HUMAN IMPACT: BIOTA AND GEOMORPHOLOGY}

Thus far I have reviewed the evidence that prehistoric Polynesians, with their transported landscapes, actively transformed the lowlands of the archipelago over the course of 14 centuries of population growth and agricultural expansion. I now turn to some specific examples of human impact on the native vegetation and fauna and on the physical environment itself.

\section{Vegetation}

The earliest explorers to visit Hawaiiwho viewed the landscape prior to the ravages of the historically introduced cattle, goats, and sheep-were struck with the generally barren and unwooded character of the lowlands. Cook and his officers remarked several times on the "woods that so remarkably surround this island [Hawaii] at a uniform distance of four and five miles from the shore" (Ledyard in Munford 1963:120). On Kauai, Vancouver reported that "the sides of the hills extending from these [taro] plantations to the commencement of the forest, a space comprehending at least one half of the island, appeared to produce nothing but a coarse spiry grass from an argillaceous soil, which had the appearance of having undergone the action of fire" (1798:170, emphasis added). The island of Kaho'olawe was described by Ellis in 1823 as "almost destitute of every kind of shrub or verdure, excepting a species of coarse grass" (1963:6).

In a masterful analysis of most available early historic descriptions of the Hilo area of Hawaii Island, McEldowney (1979) has shown that a broad zone extending from about 8 to $440 \mathrm{~m}$ elevations was dominated by cultivations interspersed among a thoroughly anthropogenic vegetation. "The cumulative effects of shifting agricultural practices (i.e., slash-and-burn or swidden), prevalent among Polynesian and Pacific peoples, probably created and maintained this open grassland mixed with pioneering species and species that tolerate light and regenerate after a fire" (1979:18-19). The vegetation of this zone had been reduced through human agency to an association of grasses, Sadleria and Gleicheniaceae ferns, the shrub Rhus sandwicensis, and feral Tacca leontopetaloides. Several early writers refer to intentional burning of this vegetation community, and McEldowney plausibly suggests the frequency of firing was intended to encourage the growth and abundance of the Sadleria and Tacca, which were used both as famine food and pig fodder (1979:23-24). Furthermore, in addition to the effects of repeated firing, the disruption of nutrient cycles in these heavily leached soils, as well as the disruption of soil structure by pig digging and agriculture, may have played significant roles in maintaining this vegetation community (McEldowney, personal communication, Sept. 1981).

Although some biologists, such as Selling (1948:44), have supposed that a grassland climax constituted the natural vegetation of the lowlands, we now have sufficient paleoenvironmental evidence to state confidently that the lowland grasslands were anthropogenic in origin. To date, the most extensive evidence has come from investigations of subfossil land snail assemblages in archaeological and geomorphological contexts. Zimmerman (1948:48) wrote of the possibilities of snail analysis: "Fossil land shells are good indicators of the character of the pre-existing forest cover in a given region, for it can be ascertained from study of them whether the forest was of the wet or dry type. Many of these species appear to have become fossil since man has so drastically upset the balance of native life in the lowlands" (see also Cooke in Brigham 1915:8).

In Halawa Valley, Molokai, intensive stratigraphic and paleomalacological studies were conducted on a series of erosional de- 
posits that form a large "fan" at the base of the valley (Kirch 1972, Kirch and Kelly 1975:55-64, 180-183). The stratified colluvial beds contained abundant terrestrial snails, as well as charcoal indicative of burning (in the lower deposits). Radiocarbon dating indicates that the erosional cycle that produced the colluvial fan began no later than A.D. 1100-1320. The terrestrial gastropods (14 species in 10 genera) leave no doubt that the vegetation on the lower valley slopes, prior to burning and subsequent erosion, consisted of native forest, perhaps dominated by Acacia koa. This forest was cleared by the Polynesian settlers of the valley, with the aid of fire, during the expansion of shifting cultivation. By the time of early European contact, the valley's vegetation had been reduced to a grassland-shrub climax.

Similar evidence of land snails in erosional deposits or associated with extensive burn layers has now been obtained from Kaho'olawe (Hommon 1980) and from several localities on Hawaii Island (Henshaw 1904, Christensen in Kirch and Clause 1981, Rosendahl 1972a). At Barbers Point, Oahu, snail deposits are situated in limestone sinks containing extinct avifauna (see below). It is probable that a majority of the extensive subfossil deposits of Carelia (Amastridae) on the island of Kauai (Cooke 1931) will be shown to date to the period of Polynesian occupation and to evidence the reduction of native forest and/or park land to the grassland climax described by Vancouver (1798).

The snail assemblages that have been studied leave no doubt that the original vegetation in these leeward areas was a climax dry forest, or, in some cases, open park land. Fosberg (1972:32-33) has termed this kind of vegetation "dryland sclerophyll forest": "In its best development this is now a low closed forest, the trees with rounded crowns. More commonly it is open, the trees not touching." The trees probably included such dry forest trees as Erythrina, Reynoldsia, Myoporum, Diospyros, Nothocestrum, Rauvolfia, Canthium, and Santalum, with the ground cover consisting of such native shrubs as Abutilon, Gossypium, Euphorbia, Nototrichium, Chenopodium, Dodonaea,
Wikstroemia, and Sida (Fosberg 1972). By the time of early European contact, only remnant pockets of this lowland vegetation remained; as we shall see, the widespread destruction of this habitat had tremendous consequences for the endemic avifauna.

The primary tool that effected these great modifications of the prehuman vegetation was undoubtedly fire. Burning for agricultural purposes was one application of fire, but there were certainly others. In 1792, Menzies "observed a large fire kindled a few miles to the eastward of Waimea [Kauai], and spreading over the face of that plain country, which was mostly covered with dry, rank grass [Heteropogon] that burnt with great rapidity" (1920:32). The inhabitants explained that the conflagration had been kindled in order that "the next crop of grass grew up clear and free of stumps, and was therefore better adapted for thatching their houses" (1920:32-33). In short, the Hawaiian case is yet another instance "where the addition by man of a single, potent factor-fire-could transform and has transformed cleared forest land into grassland" (Bartlett 1956:698, cf. Stewart 1956).

\section{Fauna}

The endemic terrestrial fauna of the archipelago consists almost solely of three groups: arthropods, nonmarine mollusks, and birds. I have already observed that several hundred molluskan species became extinct, probably through the destruction of the lowland forest habitats, and are known to science only as fossil species. Of the insects that must have inhabited these lowland forests, we know almost nothing, and can only surmise that there must formerly have been a very diverse fauna. Only within the past several years has evidence been obtained to suggest strongly that in addition to the invertebrates the Polynesian transformation of the lowland landscape resulted in the extinction of no less than half of the known avifauna of the archipelago (Olson and James, in press). The former existence of a range of birds not known in historic times was hinted at by the 
discovery of a large fossil goose (Geochen rhuax) in volcanic ash in $\mathrm{Ka}^{\mathrm{u}} \mathrm{u}$, Hawaii (Wetmore 1943). In the early 1970 s, two further extinct species, another large goose (Thambetochen chauliodous) and a flightless ibis (Apteribis glenos), were recovered from Pleistocene deposits, largely on Molokai (Olson and Wetmore 1976, Stearns 1973). Since then, investigations by Olson and his associates have revealed the former existence of no less than 38 extinct or locally extirpated species, including representatives of the following families: Procellariidae, Threskiornithidae, Anatidae, Accipitridae, Rallidae, Strigidae, Corvidae, Meliphagidae, and Drepanididae. Many of these species have been recovered from archaeological sites, or from desposits in which there is unquestioned evidence of human associations. Hence, the massive extinction of these species occurred within the period of Polynesian occupation of Hawaii, most likely through a combination of direct predation and habitat destruction (Olson and James, in press). It is no hyperbole to state that the discovery of this extinct avifauna is one of the most significant advances in Hawaiian natural history, comparable to the discovery-more than a century ago - that the Polynesians in New Zealand caused the extinction of another great insular avifauna, the moas (Cumberland 1962). We can only wonder that it has taken us so long to make the discovery!

It is known that Hawaiians exploited birds both for meat and for their plumage, and predation was doubtless one of the factors leading to the massive avifaunal extinctions. Faunal analyses from the early leeward habitation sites of $\mathrm{O} 1$ at Kuliouou, $\mathrm{Oahu}$, and $\mathrm{H} 8$ at Waiahukini, Hawaii (summarized in Table 1), document significant reductions in the quantity of birds taken over time (Emory and Sinoto 1961, Emory, Bonk, and Sinoto 1969), a reflection of human impact on the local bird populations. Olson and James (personal communication, Aug. 1981) have examined some of the $\mathrm{O} 1$ material (not previously identified to specific level) and found that it contains several extinct species.

According to Olson and James, "ulti-
TABLE 1

FREQUENCY OF BIRD BONES FROM SITES O1 AND H8

\begin{tabular}{lcc}
\hline \hline \multirow{2}{*}{$\begin{array}{c}\text { DEPTH OF } \\
\text { DEPOSIT } \\
\text { (INCH) }\end{array}$} & \multicolumn{2}{c}{ PERCENT BIRD BONE } \\
\cline { 2 - 3 } & SITE O1 & SITE H8 \\
\hline $0-6$ & 0.05 & 0.03 \\
$6-12$ & 0.33 & 0.09 \\
$12-18$ & 0.49 & 0.39 \\
$18-24$ & 8.40 & 0.63 \\
$24-25 / 30$ & 10.24 & 4.10 \\
\hline
\end{tabular}

NOTE: Frequencies given are percent of total midden by weight. Data from Emory and Sinoto (1961) and Emory et al. (1969).

mately, the cause of most of the prehistoric extinctions of Hawaiian birds was probably not predation but habitat destruction, particularly of the drier lowland forest" (in press). One of the richest and most intensively studied extinct avifaunal sites, Barbers Point, provides evidence of such habitat destruction. The Ewa Plain consists of exposed Pleistocene reef, and the resulting karst terrain, with abundant sink-holes, has provided an ideal environment for the preservation of both land snails and bird bones. Fortunately, at Barbers Point we have had the opportunity to conduct detailed stratigraphic and paleoenvironmental studies of both the mollusks and the extinct birds, and of associated archaeological features (Kirch and Christensen 1980, Olson and James 1980, Sinoto 1978). Here, I will briefly summarize the evidence from Site B6-78, a sink with an opening $1.5 \times$ $2.5 \mathrm{~m}$, one of the type localities studied over several seasons. The extinct avifauna is concentrated in layer II, $10-30 \mathrm{~cm}$ below the sink floor. Land snails in layer II indicate that this was a phase of marked environmental change, with drastic reductions (from the earlier layer III) in certain endemic taxa (Orobophana, Leptachatina, Cookeconcha, and Endodonta), and relative increases in certain other taxa preadapted to disturbed conditions (Lamellidea, Tornatellides, Lyropupa, and Succinea). Humans are indicated as the cause of these habitat changes by the presence in layer II of four of the anthropophilic animals introduced by the Polynesians to Hawaii: Rattus exulans, geckos, skinks, and the adventive snail Lamellaxis gracilis (Kirch and Christensen 1980). 
Although there has been no direct radiometric dating of these sediments or their fossil contents, when such dates are obtained, they are almost certain to confirm the association of humans with this phase of rapid ecological change and extinction of a lowland biota.

\section{Geomorphological Changes}

The impact of Polynesians in Hawaii was not confined to the biota, and evidence is beginning to accumulate which would suggest that the actions of humans had major consequences for erosion, siltation, and shoreline change. In fact, it is probable that we have yet to realize the scale of such human-induced geomorphological change. Certainly, the cases of other Pacific islands would so indicate (e.g., Kirch 1981a, Kirch and Yen, forthcoming, Spriggs 1981).

The lowland colluvial beds in Halawa Valley, Molokai, referred to above, evidence significant human-induced erosion by A.D. 1200 (Kirch and Kelly 1975). In Makaha Valley, Oahu, an inland irrigation system was partially buried under several hundred cubic meters of alluvium and slump deposit, the result of slope instability believed to have been the result of shifting cultivation upslope (Yen et al. 1972). In South Kohala on Hawaii Island, small alluvial basins contain sediment interbedded with ash, indicating that humans played a significant role in the denudation and erosion of the surrounding terrain (Rosendahl 1972b). Evidence of far more massive erosion has recently come from Kaho'olawe, where burn layers associated with extinct land snails and dated to the sixteenth century A.D. mark the beginning of a phase of erosion (Hammatt 1978, Hommon 1980). As Hommon writes: "During the 1500-1550 period, when the estimated inland population reached its maximum, it is evident that massive erosion was beginning ... extensive [prehistoric] use of the land led directly and indirectly to major erosion" (1980:7-63).

If, as these cases suggest, erosion was occurring on a fairly widespread scale by the fourteenth through sixteenth centuries, it is probable that deposition of sediments in valley bottoms and along coastlines was correspondingly accelerated. P. Beggerly and $\mathbf{J}$. Kraft (personal communication, 1981) have conducted borings in Kahana Valley, Oahu, which reveal a thin $(40-\mathrm{cm})$ alluvial deposit overlying marine sands some $590 \mathrm{~m}$ inland of the present shoreline, suggesting fairly rapid aggradation of the valley floor. Beggerly plans to extend the investigations in order to test the likely possibility that human-induced geomorphological changes are linked to this apparently rapid aggradation of the Kahana shoreline. The stratigraphic corings of Kraft (1980) in Kawainui Marsh, Oahu, have shown this physiographic feature to have been a marine embayment at the time of initial human settlement of Oahu. [An early habitation site, carbon-14 dated to ca. A.D. 500, is situated on the slopes adjacent to the marsh; Kelly and Clark (1980).] Kraft has hypothesized that construction of fish pond walls across the embayment mouth may have initiated, or at least hastened, the build up of the sand spit which turned the embayment into a marsh. In my view, these preliminary results are only indications of what will prove, upon detailed investigation, to have been major human-induced changes in shoreline configurations.

\section{SUMMARY}

Ramon Margalef's comment on humanity and evolution appropriately describes the Hawaiian microcosm: "The evolutionary play was going on in the evolutionary theatre when as part of the plot men entered, romping and stamping on the stage and bringing it almost to the point of collapse" (1968:96). Collapse may be too harsh a term, but there can no longer be any doubt that the island chain as first viewed through European eyes was a land already transformed by centuries of intensive exploitation, modification, manipulation, and, frequently, degradation. The vast tracts of grassland that covered the lowlands cannot be attributed, as Pickering (1840-1841, quoted in McEldowney 1979:22) was wont, to "a defect of creation." They were products 
of human action. Recent studies have suggested that the endemic biota was drastically affected by this habitat destruction, with perhaps one-third to one-half of the known nonmarine molluskan and bird faunas becoming extinct within the span of prehistoric human tenure. We are only beginning to understand what effects the Polynesians may have had on landforms and shorelines.

Odum (1969) and Margalef (1968) have argued that the fundamental impact of humans on ecosystems is to cause them to "regress," a reversal of the natural direction of ecological succession. Certainly, the Hawaiian case would bear this out. It is further obvious that an understanding of this sequence of human-induced transformation of the Hawaiian ecosystem should be a major goal of both natural scientists and prehistorians. For the naturalist, it cannot be assumed that the historically known biota represents a "natural" one (consider the implications for biogeographic and evolutionary models of an extinct avifauna twice as diverse as previously assumed). For the prehistorian, the evolutionary development of Hawaiian culture must be viewed in the context of a changing environment that continued to place selection pressures upon the human population and its adaptive strategies - pressures in large part due to the actions of humans themselves.

To some who read the above arguments that the prehistoric Polynesian inhabitants of Hawaii seriously transformed and, in many instances, degraded their island ecosystem, the nagging question may occur: What of the proposition, often cited, that the Hawaiians and other oceanic peoples had a conservationist approach to nature? It is certainly true that various resource management measures (such as the imposition of a kapu, or ban, on certain fish; Malo 1951:209) were enacted at times to reduce the impact of exploitation on certain resources. But the existence of a conservation ethic and its effectiveness are two different things; the former does not automatically imply the latter. To paraphrase Anderson $(1979: 64)$ on a case of Maori overexploitation of shellfish in New Zealand, it would be invidious to suggest that the prehistoric Hawaiians were ignorant or unsympathetic to the needs or importance of conservation. Yet, given their burgeoning population and technological limits, conservation "may well have been a luxury they could simply not afford."

\section{ACKNOWLEDGMENTS}

I am grateful to Storrs Olson and Helen James of the Smithsonian Institution for supplying me with a copy of their manuscript on the extinct avifauna of Hawaii. Carl Christensen and Holly McEldowney both read earlier drafts of this paper and provided useful commentary. Alison Kay also offered several editorial comments.

\section{LITERATURE CITED}

Allen, M. S. 1981. An analysis of the Mauna Kea Adz Quarry archaeobotanical assemblage. M. A. Thesis. University of Hawaii, Honolulu.

Ammerman, A. J., L. L. Cavalli-Sforza, and D. K. WAGEnER. 1976. Toward the estimation of population growth in Old World prehistory. Pages 27-61 in E. Zubrow, ed. Demographic anthropology. University of New Mexico Press, Albuquerque.

Anderson, A. J. 1979. Prehistoric exploitation of marine resources at Black Rocks Point, Palliser Bay. Pages 49-65 in B. F. Leach and H. M. Leach, eds. Prehistoric man in Palliser Bay. Bull. Nat. Mus. N. Z. 21.

Anderson, E. 1952. Plants, man, and life. University of California Press, Berkeley.

Atkinson, I. A. E. 1977. A reassessment of the factors, particularly Rattus rattus L., that influenced the decline of endemic forest birds in the Hawaiian Islands. Pac. Sci. 31:109-133.

Barrau, J. 1965. L'humide et le sec: An essay on ethnobiological adaptation to 
contrastive environments in the IndoPacific area. J. Polynesian Soc. 74:329346.

Bartlett, H. H. 1956. Fire, primitive agriculture, and grazing in the tropics. Pages 692-720 in W. L. Thomas, ed. Man's role in changing the face of the earth. Vol. 2. University of Chicago Press, Chicago.

BAtes, M. 1956. Man as an agent in the spread of organisms. Pages 788-804 in W. L. Thomas, ed. Man's role in changing the face of the earth. Vol. 2. University of Chicago Press, Chicago.

Bonk, W. J. 1954. Archaeological excavations on West Molokai. M. A. Thesis. University of Hawaii, Honolulu.

Brigham, W. T. 1915. Director's report for 1914. Occ. Pap. Bernice P. Bishop Mus. 6(2).

Carlquist, S. 1970. Hawaii: A natural history. Natural History Press, New York.

Christensen, C. C., and P. V. KirCh. 1981. Nonmarine mollusks from archaeological sites on Tikopia, Southeastern Solomon Islands. Pac. Sci. 35: 75-88.

Cooke, C. M., JR. 1926. Notes on Pacific land snails. Proc. 3d. Pac. Sci. Congr. (Tokyo) 2276-2284.

1931. The land snail genus Carelia. Bull. Bernice P. Bishop Mus. 85.

Cooke, C. M., JR., and Y. Kondo. 1960. Revision of Tornatellinidae and Achatinellidae. Bull. Bernice P. Bishop Mus. 221:1-303.

CoRDY, R. 1978. A study of prehistoric social change: The development of complex societies in the Hawaiian Islands. Ph.D. Thesis. University of Hawaii, Honolulu.

Cumberland, K. B. 1962. Moas and men: New Zealand about A.D. 1250. Geogr. Rev. 52:151-173.

Degener, T., and I. Degener. 1974. Appraisal of Hawaiian taxonomy. Phytologia 29(3): 240-246.

EARLE, T. 1978. Economic and social organization of a complex chiefdom: The Halelea District, Kauai, Hawaii. Anthrop. Pap. Mus. Anthrop., University of Michigan 63.

EGLER, F. 1942. Indigene versus alien in the development of arid Hawaiian vegetation. Ecology 23(1): 14-23.

Ellis, W. 1963. Journal of William Ellis. Advertiser Publishing Co., Honolulu. (Reprint of 1827 London edition.)

EMORY, K. P., and Y. H. Sinoto. 1961. Hawaiian archaeology: Oahu excavations. Bernice P. Bishop Mus. Spec. Publ. 49.

EMORY, K. P., W. J. BonK, and Y. H. Sinoto. 1969. Waiahukini shelter, Site H8, Ka'u, Hawaii. Pac. Anthrop. Rec. 7.

EwING, H. E. 1924. Ectoparasites of some Polynesian and Malaysian rats of the genus Rattus. Bull. Bernice P. Bishop Mus. 14.

FERRIS, G. F. 1932. Ectoparasites of Marquesan rats. Bull. Bernice P. Bishop Mus. 98.

FosBerg, F. R. 1963. The island ecosystem. Pages 1-6 in F. R. Fosberg, ed. Man's place in the island ecosystem. Bishop Museum Press, Honolulu.

1972. Guide to Excursion III, 10th Pac. Sci. Congr. (rev. ed.). University of Hawaii, Honolulu.

Green, R. C., ed. 1969. Makaha Valley historical project: Interim report no. 1 . Pac. Anthrop. Rec. 4.

1970. Makaha Valley historical project: Interim report no. 2. Pac. Anthrop. Rec. 10.

Hammatт, H. H. 1978. Geoarchaeological stratigraphy in the Hawaiian Islands. Paper, 43d Ann. Meet., Soc. Amer. Archaeol., Tucson.

Handy, E. S. C., and E. G. Handy. 1972. Native planters in old Hawaii: Their life, lore, and environment. Bull. Bernice P. Bishop Mus. 233.

Henshaw, H. W. 1904. On certain deposits of semi-fossil shells in Hamakua District, Hawaii, with descriptions of new species. J. Malacol. 2(3) : 56-64.

Hommon, R. J. 1976. The formation of primitive states in pre-contact Hawaii. Ph.D. Thesis. University of Arizona, Tucson.

- 1980. Multiple resources nomination, Kaho'olawe Archaeological Sites, National Register of Historic Places, Washington, D.C. 
Kelly, M. 1975. Loko I‘a O He'eia: Heeia fishpond. Anthrop. Dept. Rept. 75-2, Bernice P. Bishop Mus., Honolulu.

Kelly, M., and J. Clark. 1980. Kawainui Marsh, O'ahu: Historical and archaeological studies. Anthrop. Dept. Rept. 80-3, Bernice P. Bishop Mus., Honolulu.

KIRCH，P. V. 1972. Subfossil non-marine gastropods from Molokai, Hawaiian Islands. Nautilus 86(1):23.

- 1977. Valley agricultural systems in prehistoric Hawaii: An archaeological consideration. Asian Perspectives 20(2): 246-280.

1980. Demographic archaeology in an isolated ecosystem: The dynamics of population growth in prehistoric Hawaii. Manuscript, Anthrop. Dept., Bernice P. Bishop Mus., Honolulu.

. 1981a. Lapitoid settlements of Futuna and Alofi, Western Polynesia. Archaeology in Oceania 16(3): 127-143.

- 1981b. Agricultural intensification in Polynesia: The leeward Hawaiian field systems. Paper, Conf. Prehistoric Intensive Agr. in the Tropics, Australian National University, Canberra.

Kirch, P. V., and C. C. Christensen. 1980. Nonmarine molluscs and paleoecology at Barbers Point, O'ahu. Prepared for U.S. Army Corps of Engineers, Honolulu. Manuscript no. 070280, Anthrop. Dept., Bernice P. Bishop Mus., Honolulu.

Kirch, P. V., and B. T. Clause, eds. 1981. The Mudlane-Waimea-Kawaihae archaeological project: Interim report 1. Anthrop. Dept., Bernice P. Bishop Mus., Honolulu.

KIRCH, P. V., and M. Kelly, eds. 1975. Prehistory and human ecology in a windward Hawaiian valley: Halawa Valley, Molokai. Pac. Anthrop. Rec. 24.

KIRCH, P. V., and D. E. Yen. Forthcoming. Tikopia: Prehistory and ecology of a Polynesian outlier. Bull. Bernice P. Bishop Mus. 238.

Kraft, J. C. 1980. Summary of results of the Kawainui Marsh study. Letter to Coastal Zone Management Program, State of Hawaii. 18 Dec. 1980.

LADD, E. J., and D. E. YEN, eds. 1972.
Makaha Valley historical project: Interim report no. 3. Pac. Anthrop. Rec. 18.

McEldowney, H. 1979. Archaeological and historical literature search and research design, Lava Flow Control Study, Hilo, Hawaii. Manuscript no. 050879, Anthrop. Dept., Bernice P. Bishop Mus., Honolulu. Prepared for U.S. Army Corps of Engineers, contract no. DACW84-77-C-0019.

Malo, D. 1951. Hawaiian antiquities 2d. ed. N. B. Emerson, trans. Bernice P. Bishop Mus. Spec. Publ. 2.

Margalef, R. 1968. Perspectives in ecological theory. University of Chicago Press, Chicago.

MenZies, A. 1920. Hawaii Nei 128 years ago. W. F. Wilson, ed. Honolulu.

Munford, J. K., ed. 1963. John Ledyard's journal of Captain Cook's, last voyage. Oregon State University Press, Corvallis.

Newman, T. S. N.d. Hawaiian fishing and farming on the island of Hawaii, A.D. 1778. Dept. Land and Nat. Resources, Div. State Parks, Honolulu.

Odum, E. 1969. The strategy of ecosystem development. Science 164:262-270.

Olson, S. L., and H. F. James. 1980. Paleontological salvage at Barbers Point, O'ahu. Report prepared for Archaeological Research Center Hawaii, Inc., Lawai, Kauai.

- In press. Prodromus of the fossil avifauna of the Hawaiian Islands. Smithsonian Contrib. Zool.

Olson, S. L., and A. Wetmore. 1976. Preliminary diagnoses of two extraordinary new genera of birds from Pleistocene deposits in the Hawaiian Islands. Proc. Biol. Soc. (Washington) 89 (18): 247-258.

Pearson, R. J., P. V. Kirch, and M. PietrusewSKy. 1971. An early prehistoric site at Bellows Beach, Oahu, Hawaiian Islands. Archaeol. Phys. Anthrop. Oceania 6(3): 204-234.

Pilsbry, H. A. 1916-1918. Manual of conchology. Vol. 24. Pupillidae. Academy of Natural Sciences, Philadelphia.

Rosendahl, P. H. 1972a. Aboriginal agriculture and residence patterns in upland Lapakahi, Island of Hawaii. Ph.D. Thesis. University of Hawaii, Honolulu. 
1972b. Archaeological salvage of the Hapuna-Anaehoomalu section of the Kailua-Kawaihae Road, Island of Hawaii. Anthrop. Dept. Rept. 72-5, Bernice P. Bishop Mus., Honolulu.

SAhlins, M. 1964. Culture and environment: The study of cultural ecology. Page 133 in S. Tax, ed. Horizons of anthropology. Aldine, Chicago.

Schilt, A. R. 1980. Archaeological investigations in specified areas of the Hanalei Wildlife Refuge, Hanalei Valley, Kaua'i. Manuscript no. 101680, Anthrop. Dept., Bernice P. Bishop Mus., Honolulu.

Schmitt, R. C. 1971. New estimates of the pre-censal population of Hawaii. J. Polynesian Soc. 80 (2) : 237-243.

Selling O. H. 1948. Studies in Hawaiian pollen statistics. Part III. On the late Quaternary history of the Hawaiian vegetation. Bernice P. Bishop Mus. Spec. Publ. 39.

Sinoto, A. 1978. Archaeological and paleontological salvage at Barbers Point, Oahu. Manuscript no. 030178, Anthrop. Dept., Bernice P. Bishop Mus., Honolulu.

Soemren, L. J., and T. S. Newman. 1968. The archaeology of Kealakekua. Spec. Publ., Anthrop. Dept., Bernice P. Bishop Mus., and University of Hawaii. Prepared for Lt. Governor's Office, State of Hawaii, Honolulu.

Solem, A. 1959. Systematics and zoogeography of the land and freshwater mollusca of the New Hebrides. Fieldiana: Zool. 43.

SpRIGGS, M. 1981. Gone with the rain. Paper, Anthrop. Dept. Colloq., University of Hawaii, Honolulu.

St. John, H. 1978. The first collection of Hawaiian plants by David Nelson in 1779. Pac. Sci. 32 (3): 315-324.

Stearns, H. T. 1973. Geologic setting of the fossil goose bones found on Molokai Island, Hawaii. Occ. Pap. Bernice P. Bishop Mus. 24 (10): 155-163.

Stejneger, L. 1899. The land reptiles of the Hawaiian Islands. Proc. U.S. Nat. Mus. $21: 783-813$.

Stewart, O. C. 1956. Fire as the first great force employed by man. Pages 115-133 in W. L. Thomas, ed. Man's role in changing the face of the earth. Vol. 1. University of Chicago Press, Chicago.

Tate, G. H. H. 1951. The rodents of Australia and New Guinea. Bull. Amer. Mus. Nat. Hist. 97 (4) : 187-430.

Tuggle, H. D., and P. B. Griffin, eds. 1973. Lapakahi, Hawaii: Archaeological studies. Asian Pac. Archaeol. Ser. No. 5.

VANCOUVER, G. 1798. A voyage of discovery to the North Pacific Ocean and round the world.... Performed in the years 1790-95. London.

Wetmore, A. 1943. An extinct goose from the Island of Hawaii. Condor 45:146-148.

YEN, D. E. 1973. The origins of Oceanic agriculture. Archaeol. Phys. Anthrop. Oceania 8:68-85.

1974. The sweet potato and Oceania. Bull. Bernice P. Bishop Mus. 236.

YEN, D. E., P. V. Kirch, P. Rosendahl, and T. RILEY. 1972. Prehistoric agriculture in the upper valley of Makaha, Oahu. Pages 59-94 in E. Ladd and D. Yen, eds. Makaha Valley historical project: Interim report no. 3. Pac. Anthrop. Rec. 18.

Zimmerman, E. C. 1948. Insects of Hawaii. Vol. 1. Introduction. University Press of Hawaii, Honolulu.

1963. Nature of the land biota. Pages 57-64 in F. R. Fosberg, ed. Man's place in the island ecosystem. Bishop Museum Press, Honolulu. 